\title{
Persistence of Hepatitis A Virus RNA in Water, on Non-porous Surfaces, and on Blueberries
}

OPEN ACCESS

Edited by: Walter Randazzo,

University of Valencia, Spain

Reviewed by:

Matthew D. Moore,

University of Massachusetts Amherst,

United States

Dan Li,

National University of Singapore,

Singapore

${ }^{*}$ Correspondence:

Julie Jean

julie.jean@fsaa.ulaval.ca

Specialty section:

This article was submitted to

Food Microbiology,

a section of the journal

Frontiers in Microbiology

Received: 16 October 2020

Accepted: 15 January 2021

Published: 04 February 2021

Citation:

Trudel-Ferland $M$, Jubinville $E$ and Jean J (2021) Persistence of Hepatitis A Virus RNA in Water, on Non-porous

Surfaces, and on Blueberries.

Front. Microbiol. 12:618352.

doi: 10.3389/fmicb.2021.618352

\section{Mathilde Trudel-Ferland, Eric Jubinville and Julie Jean*}

Institute of Nutrition and Functional Foods (INAF), Université Laval, Quebec City, QC, Canada

Enteric viruses, such as human norovirus and hepatitis A virus (HAV), are the leading cause of transmissible foodborne illness. Fresh produce such as berries are often contaminated by infected food handlers, soiled water, or food contact surfaces. The gold-standard method for virus detection throughout the food chain is RT-qPCR, which detects portions of genomes including non-infectious viral particles and naked viral RNA. The aim of this study was to evaluate the persistence of heat-inactivated HAV in water, phosphate-buffered saline, on stainless steel and polyvinyl chloride, and on blueberries at $-80^{\circ} \mathrm{C},-20^{\circ} \mathrm{C}, 4^{\circ} \mathrm{C}$, and room temperature. In water and phosphate-buffered saline, viral RNA could be detected for up to 90 days regardless of temperature when the initial load was $2.5 \times 10^{4}$ or $2.5 \times 10^{6}$ genome copies. It was detected on polyvinyl chloride and blueberries under most conditions. On stainless steel, the large initial load persisted for 90 days, while the medium-level load was detected only up to 16 days at room temperature or 60 days at $4^{\circ} \mathrm{C}$. The detection of non-infectious viral RNA can confound investigations of gastroenteritis outbreaks. Pretreatments that discriminate between naked RNA, non-infectious virions and infectious virions need to be included in the RT-qPCR method in order to reduce the risk of positive results associated with non-infectious viral particles.

Keywords: persistence, RNA, hepatitis A, water, food contact surfaces, blueberries

\section{INTRODUCTION}

Enteric viruses such as human noroviruses (NoV) and hepatitis A virus (HAV) are a leading cause of foodborne illness worldwide. During the past decade, NoV infections numbered at least 124 million per year and HAV infection numbered 13 million per year (WHO, 2015). NoV usually leads to acute gastroenteritis after an incubation period of 24-48 h (Patel et al., 2009). Although the illness lasts for only 2 or 3 days in most cases, its prevalence makes it a global economic burden (Patel et al., 2009; Bartsch et al., 2016a). In the case of HAV, the incubation period ranges from 14 to 28 days, and the subsequent acute hepatitis may last up to 2 months (Lemon et al., 2018). Asymptomatic infections are fairly common, and the disease is endemic in many countries, the majority of cases occurring in early childhood. Although HAV infection is less common in countries with high standards of hygiene, symptomatic infection with a higher risk of hospitalization and death is more frequent since few adults have acquired immunity (Koopmans and Duizer, 2004; Jacobsen, 2018). 
As international trade accelerates, non-endemic countries are experiencing increased numbers of outbreaks of foodborne viral diseases (Tavoschi et al., 2015; Jacobsen, 2018).

Enteric viruses are excreted in high concentrations in feces and to a lesser extent in vomitus and aerosols. Infected individuals can excrete anywhere from $10^{6}$ to a $10^{11}$ copies of NoV or HAV genome per gram of feces (Tjon et al., 2006; Atmar et al., 2008; Bonifait et al., 2015) and may therefore contaminate readyto-eat or minimally processed foods such as fruits, vegetables, and shellfish as well as surfaces where these products are sorted and packaged. Other contamination routes are sewage-polluted irrigation water and fishing sites (Kokkinos et al., 2012; Lopman et al., 2012; Verhaelen et al., 2013; Randazzo and Sánchez, 2020). Leafy vegetables, such as lettuce, mixed salads, and green onions, are the most frequently contaminated vegetables (Wheeler et al., 2005; Herman et al., 2015), whereas berries are frequently contaminated fruits (Chatziprodromidou et al., 2018; Nasheri et al., 2019). Enteric viruses can remain infectious under harsh environmental conditions, and imported frozen fruits have been involved in recent outbreaks in industrialized countries (Bernard et al., 2014; Collier et al., 2014; Severi et al., 2015; Franklin et al., 2019; Nasheri et al., 2019). This has led governmental bodies such as the U.S. Food and Drug Administration and the Canadian Food Inspection Agency to establish surveillance plans for viruses in fresh and frozen fruits (Canadian Food Inspection Agency, 2017; U.S. Food and Drug Administration, 2020a).

For detecting viruses in foods, genomic methods have been preferred over titration of infectious particles because they are less tedious and yield results much sooner (Croci et al., 2008). However, these methods raise the issue of non-infectious viral RNA potentially influencing decision-making. This has been examined in the CFIA surveillance report on viruses in fruits and the difficulty of assessing real health risks associated with the consumption of foods positive for viral RNA (Canadian Food Inspection Agency, 2017). The FDA currently recommends using RT-qPCR to detect HAV or NoV in berries, followed by Sanger sequencing to confirm a positive result before suggesting that the producer or distributor involved recalls the lot (U.S. Food and Drug Administration, 2020a,b). Since such product recalls can be financially ruinous to businesses in the food industry, means of recognizing positive tests that are due only to infectious RNA must be found.

Noroviruses and HAV both have a positive-sense, singlestranded RNA genome enclosed in a non-enveloped capsid, the latter being a key factor in their persistence in the environment and resistance to viral inactivation treatments (Girard et al., 2010; Vasickova et al., 2010; Jean et al., 2011; Escudero et al., 2012; Cook et al., 2018; Leblanc et al., 2019). It is widely accepted that infectious NoV, HAV, and their surrogate viruses persist in different waters (Biziagos et al., 1988; Cook et al., 2018), on common surfaces in the food industry (D'Souza et al., 2006; Mattison et al., 2007; Bae et al., 2014), and in food matrices (Butot et al., 2008; Lamhoujeb et al., 2008; Leblanc et al., 2019). However, data on the persistence and significance of non-infectious viral RNA on or in foods are extremely scarce (Limsawat and Ohgaki, 1997; D’Souza et al., 2006; Escudero et al., 2012).
The aim of this study was to evaluate the persistence of inactivated HAV detectable by RT-qPCR in pure water (molecular biology grade) and phosphate-buffered saline, on common non-porous surfaces (stainless steel and polyvinyl chloride), and on blueberries. The effects of temperature, time, and initial concentration on the stability of the inactivated viral genome were examined.

\section{MATERIALS AND METHODS}

\section{Preparation of the Viral Stock Suspension}

FRhK-4 cells (ATCC ${ }^{\circledR}$ CRL-1688) were cultured as described previously (Mbithi et al., 1991). Briefly, cells were grown in Eagle's Minimal Essential Medium (product 320-005-CL, Wisent Inc., St-Bruno-de-Montarville, QC, Canada) supplemented with $10 \%$ fetal bovine serum (product 080-150, Wisent Inc., Canada), 2 mM L-glutamine (product 609-065-EL, Wisent Inc., Canada), $1 \%$ non-essential amino acid mixture (product 321-011-EL, Wisent Inc., Canada), $10 \mathrm{mM}$ HEPES (product 330-050-EL, Wisent Inc., Canada), 0.113\% sodium bicarbonate (product 609-105-EL, Wisent Inc., Canada), $50 \mathrm{IU} / \mathrm{mL}$ penicillin, and $50 \mu \mathrm{g} / \mathrm{mL}$ streptomycin (product 450-200-EL, Wisent Inc., Canada).

Cytopathogenic HAV strain HM-175, obtained from the Bureau of Microbial Hazards, Health Canada, Ottawa, ON, was propagated as described previously (Mbithi et al., 1992). Viral titer was measured by plaque assay as described previously (Mbithi et al., 1991). Briefly, FRhK-4 monolayers were grown in 12-well culture plates (product3336, Corning Inc., Glendale, AZ, United States) for $24 \mathrm{~h}$ at $37^{\circ} \mathrm{C}$ with $5 \% \mathrm{CO}_{2}$. Serial dilutions $(300 \mu \mathrm{L})$ were inoculated in duplicate. Phosphate-buffered saline (PBS, product 21-040-CV, Corning Inc., United States) alone was included as a negative plaque assay control. The plates were incubated at $37^{\circ} \mathrm{C}$ for $90 \mathrm{~min}$, oscillated gently every $30 \mathrm{~min}$ and then overlaid with $3 \mathrm{~mL}$ of Minimum Essential Medium (product 220-005-XK, Wisent Inc., Canada), containing 2\% fetal bovine serum, $2 \mathrm{mM}$ L-glutamine, $1 \%$ non-essential amino acids, $10 \mathrm{mM}$ HEPES, $0.113 \%$ sodium bicarbonate, $50 \mathrm{IU} / \mathrm{mL}$ penicillin and $50 \mu \mathrm{g} / \mathrm{mL}$ streptomycin, $0.5 \%$ magnesium chloride (product CAJT244-1, Avantor Inc., Radnor, PA, United States), and 1\% ultra-pure agarose (product 15510-027, Invitrogen Canada Inc., Burlington, ON, Canada). The plates were incubated for 8 days at $37^{\circ} \mathrm{C}$ with $5 \% \mathrm{CO}_{2}$, the overlay was then removed, and the cell layers were fixed and stained as described previously (Sattar et al., 1989). The HAV stock suspension $\left(2.24 \times 10^{5} \mathrm{pfu} / \mathrm{mL}\right)$ was stored at $-80^{\circ} \mathrm{C}$ until RNA extraction.

\section{Inactivated Viral Stock Suspension}

Concentrated inactivated HAV was prepared as described elsewhere (Suresh et al., 2019) with modifications. Briefly, the HAV stock suspension was diluted $1 / 10$ in PBS and then inactivated at $100^{\circ} \mathrm{C}$ for $10 \mathrm{~min}$ in a water bath. Inactivation was confirmed by plaque assay. Inactivated HAV was quantitated by RT-qPCR. The stock suspension of inactivated HAV $\left(1.22 \times 10^{5}\right.$ genome copies $/ \mu \mathrm{L}$ ) was stored at $-80^{\circ} \mathrm{C}$ until experiments. 


\section{Real-Time Reverse-Transcriptase PCR}

The HAV genome was amplified using iTaq Universal probe 1step (Bio-Rad, Hercules, CA, United States) on an ABI7500 realtime PCR System (Applied Biosystems, Thermo Fisher Scientific, Waltham, MA, United States) using the SDSv1.3 program. Primers [Integrated DNA Technologies (IDT), Coralville, IA, United States] and probe (Applied Biosystems, United States) were used as described previously (Costafreda et al., 2006). The reaction volume consisted of $10 \mu \mathrm{L}$ of iTaq universal probes reaction mixture $(2 \times), 250 \mathrm{nM}$ of each primer and probe, $0.5 \mu \mathrm{L}$ of iScript advanced reverse transcriptase, $2.63 \mu \mathrm{L}$ RNAase-free water, and $5 \mu \mathrm{L}$ of RNA sample for a total reaction volume of $20 \mu \mathrm{L}$. All samples were plated manually in 96-well half-skirt clear PCR microplates (product PCR-96-HSAC-C, Axygen, Glendale, AZ, United States) and then sealed with optical adhesive film (LS4360954, Applied Biosystems, United States). Sample and procedural control reactions were performed in duplicate. Molecular -biology-grade water (product L0201, VWR, United States) was used as a negative RT-qPCR control. Reverse transcription was performed at $50^{\circ} \mathrm{C}$ for $10 \mathrm{~min}$ followed by polymerase activation and DNA denaturation at $95^{\circ} \mathrm{C}$ for $3 \mathrm{~min}$ and 45 cycles of $95^{\circ} \mathrm{C}$ for $15 \mathrm{~s}$ and $60^{\circ} \mathrm{C}$ for $30 \mathrm{~s}$ as recommended by the manufacturer. ROX dye was used as a reference dye. Genome copies were quantified using a dsDNA standard curve generated using sequential 10-fold dilutions of dsDNA plasmid pIDTSmart-AMP (IDT, United States) carrying the target sequence described in ISO 15216-1:2017 Appendix G (Anonymous, 2017). Standard curve reactions were performed in triplicate. All standard curve efficiencies were between 90 and $110 \%$ with $R^{2}$ values superior to 0.98 and thus met the ISO standard.

\section{Test Surfaces}

\section{Non-porous Surfaces}

Disks of stainless steel (Acier Inoxydable Den-Mar Inc., Quebec City, QC, Canada) and polyvinyl chloride (PVC type1, grade1, Plastique Polyfab, Quebec City, QC, Canada) $1 \mathrm{~cm}$ in diameter were cleaned in $6.5 \%$ sodium hypochlorite for $15 \mathrm{~min}$, rinsed in sterile deionized water and then cleaned in $70 \%$ ethanol for $15 \mathrm{~min}$ and allowed to dry. Stainless steel was then autoclaved at $121^{\circ} \mathrm{C}$ for $20 \mathrm{~min}$, and PVC was decontaminated on each side using UV $(254 \mathrm{~nm})$ for $15 \mathrm{~min}$ in a laminar flow hood (Jean et al., 2011). The sterile disks were placed in 12 -well plates prior to application of inactivated HAV.

\section{Food Surface}

Blueberries purchased in a local supermarket were washed three times in sterile deionized water. The fruits were dried, disposed calyx down in 12-well plates, and decontaminated using UV light for 30 min prior to application of inactivated HAV (Girard et al., 2016).

\section{RNA Persistence Study}

Microtubes received inactivated HAV (containing RNA) stock suspension diluted to $2.5 \times 10^{6}, 2.5 \times 10^{4}$, or $2.5 \times 10^{2}$ genome copies per $100 \mu \mathrm{L}$ of PBS or molecular-biology-grade water. Negative procedural control microtubes received $100 \mu \mathrm{L}$ of diluent alone. The microtubes were stored at $-80^{\circ} \mathrm{C},-20^{\circ} \mathrm{C}$, $4^{\circ} \mathrm{C}$, or $23^{\circ} \mathrm{C}$ (controlled ambient temperature). Inactivated HAV was assayed after $30 \mathrm{~min}, 6 \mathrm{~h}, 24 \mathrm{~h}, 48 \mathrm{~h}, 4$ days, 8 days, 16 days, 2 months, and 3 months. Frozen solution samples were thawed on ice for the same duration. Furthermore, all procedural controls were submitted to the same conditions. Positive procedural controls (positive control $\mathrm{T}_{0}$ ) consisting of fresh dilutions (in PBS or water) of the inactivated HAV suspension were prepared on the day of analysis and included in each assay. These controls were used to calculate the RNA detection in solutions.

For surfaces, $20 \mu \mathrm{L}$ of inactivated HAV (containing RNA, capsids, etc.) dilution thereof was placed on a disk or blueberry and allowed to dry for $1 \mathrm{~h}$ in a PCR workstation AC600 (AirClean Systems, Creedmoor, NC, United States). Two initial loads were tested: $2.5 \times 10^{6}$ and $2.5 \times 10^{4}$ genome copies per repetition. Negative procedural control surfaces received $20 \mu \mathrm{L}$ of diluent alone. The end of the drying period marked time 0 . Disks were stored at $4^{\circ} \mathrm{C}$ and $23^{\circ} \mathrm{C}$, whereas blueberries were stored at $4^{\circ} \mathrm{C}$ and $-20^{\circ} \mathrm{C}$. Inactivated HAV was assayed at the same time points as in the persistence experiment in solutions. The blueberry surface was not analyzable beyond 16 days when stored at $4^{\circ} \mathrm{C}$. Inactivated HAV was eluted from the surfaces using a modified version of a technique described previously (Escudero et al., 2012). Briefly, $50 \mu \mathrm{L}$ of molecular-biology-grade water was pipetted 25 times over the surface and then collected. The process was repeated with another $50 \mu \mathrm{L}$ of water to obtain a final eluate volume of $100 \mu \mathrm{L}$. Positive procedural controls consisting of a fresh dilution of inactivated HAV suspension were included at each time point. These controls prepared on the day of analysis allow to calculate the RNA detection on surfaces ([RNA $]_{\text {positivecontrolT0 }}$ ). Previously described positive controls were also used to measure the inactivated HAV elution efficiency on PVC (45\%), SS (27\%), and blueberries (21\%; data not shown). Eluates were analyzed immediately and then stored at $-80^{\circ} \mathrm{C}$. RNA detection was calculated for the test samples using the following equation unless written otherwise:

$$
R N A \text { detected }(\%)=\frac{[R N A]_{\text {sample } T_{n}}}{[R N A]_{\text {positive control } T_{0}}} \times 100
$$

where $[\mathrm{RNA}]$ is the copy number.

However, presence or absence of genome copies was analyzed in water containing $2.5 \times 10^{2}$ genome copies $/ 100 \mu \mathrm{L}$ and PBS solutions.

\section{Statistical Analysis}

All RT-qPCR assays were performed in duplicate, and all experiments were replicated three times except for analyses in PBS, which were performed twice. Data were analyzed using GraphPad Prism version 8.4.0. A two-way analysis of variance (ANOVA) followed by a Tukey's multiple comparisons test was used to determine the temperature $\times$ time interaction and the initial inactivated HAV load $\times$ time interaction effects on \% RNA detected in suspensions. For persistence on surfaces, a three-way analysis of variance (ANOVA) followed by a Tukey's multiple comparisons test was used to reveal interactions between 
temperature, time and surface type and between temperature, time and initial RNA load on blueberries stored for up to 16 days. Differences in \% RNA detected were considered significant at $p<0.05$.

\section{RESULTS}

\section{Persistence of Inactivated HAV in Suspension}

As shown in Figure 1, inactivated HAV remained detectable in pure water stored at all four temperatures for at least 90 days when the initial load was $2.5 \times 10^{6}$ or $2.5 \times 10^{4}$ genome copies. A time $\times$ temperature interaction $(p=0.0017)$ was observed at the higher initial RNA concentration (Figures 1A,B). Detectable RNA dropped sharply from this concentration after only $24 \mathrm{~h}$ at $23^{\circ} \mathrm{C}$ compared to $-20^{\circ} \mathrm{C}$ or $-80^{\circ} \mathrm{C}$. A considerable drop was also observed at $4^{\circ} \mathrm{C}$. This difference remained significant for
90 days except on day $16(p=0.0812)$. The differences between -20 and $-80^{\circ} \mathrm{C}$ were never significant. Inactivated $\mathrm{HAV}$ was nevertheless still detected after 90 days of storage at $23^{\circ} \mathrm{C}(8.67 \%)$ and $4^{\circ} \mathrm{C}(14.67 \%)$.

Starting from the lower initial load (Figures 1C,D), although no interaction between time and temperature was apparent, each of these factors by itself had a significant effect on detectable RNA ( $p=0.0094$ and $<0.0001$, respectively). The temperature effect at 60 and 90 days was less consistent than it was in the case of the higher initial load. Inactivated HAV was still detected after 90 days regardless of storage temperature. Starting from a much lower initial load of 250 copies, negative results (RNA not detected) were obtained only at temperatures above freezing, and with one exception, only after 60 days of storage (Table 1). At $-20^{\circ} \mathrm{C}$ and $-80^{\circ} \mathrm{C}$, inactivated HAV was detected in at least one of three replicates at 60 and 90 days.

As shown in Table 2, inactivated HAV was detected for up to 90 days at any of the four temperatures when suspended in PBS

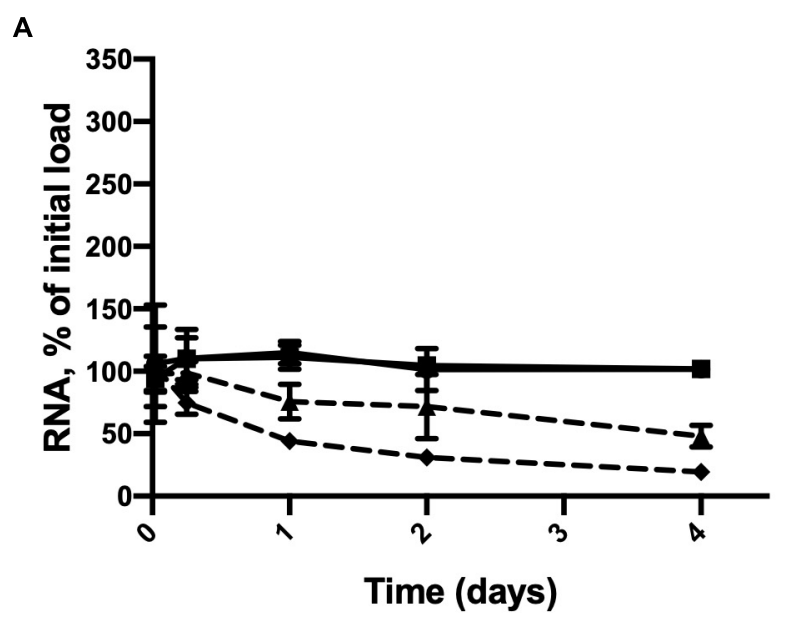

B
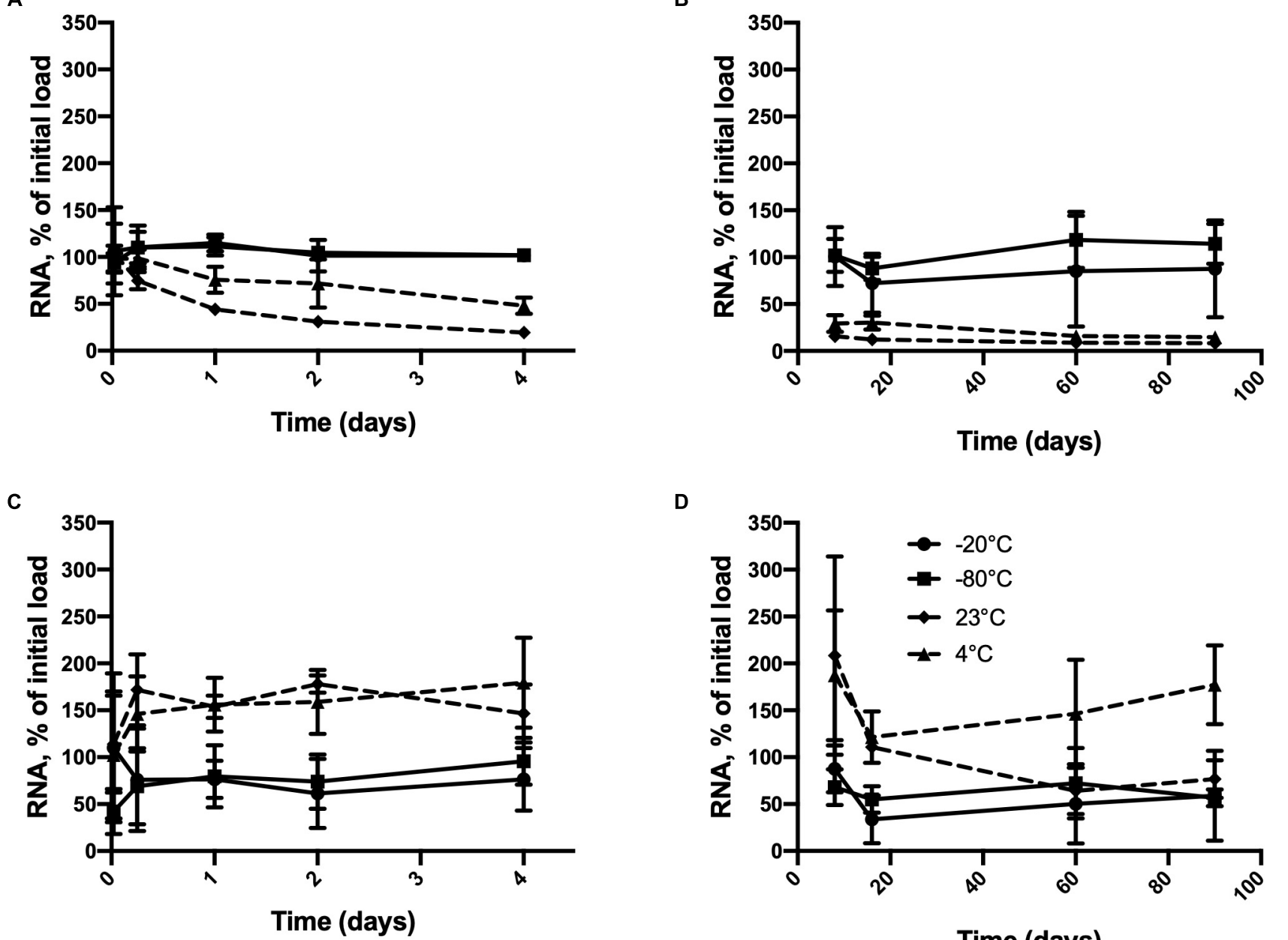

D

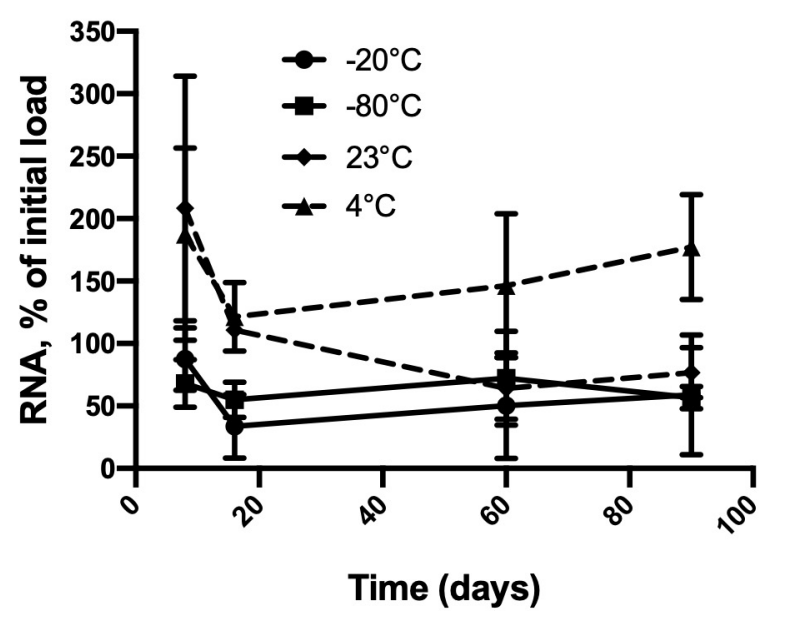

FIGURE 1 | Persistence of inactivated HAV in water (molecular biology grade) initially at $2.5 \times 10^{6}$ genome copies per $100 \mu \mathrm{L}$ from (A) 30 min to 4 days and (B) 8 days to 90 days and at $2.5 \times 10^{4}$ genome copies per $100 \mu \mathrm{L}$ from (C) 30 min to 4 days and (D) 8 days to 90 days at $-80^{\circ} \mathrm{C}(-),-20^{\circ} \mathrm{C}(\rightarrow-), 4^{\circ} \mathrm{C}(\rightarrow-)$, and $23^{\circ} \mathrm{C}(\bullet-)$. Plotted values are means of 3 repetitions \pm standard deviation. 
TABLE 1 | Detection of inactivated HAV in water (molecular biology grade) over time at $-80^{\circ} \mathrm{C},-20^{\circ} \mathrm{C}, 4^{\circ} \mathrm{C}$, and $23^{\circ} \mathrm{C}$ starting from an initial load of $2.5 \times 10^{2}$ in $100 \mu \mathrm{L}$.

\begin{tabular}{cccccc}
\hline Temperature $\left({ }^{\circ} \mathbf{C}\right)$ & $\mathbf{- 8 0}$ & $\mathbf{- 2 0}$ & $\mathbf{4}$ & $\mathbf{2 3}$ \\
\hline Time & 30 min & 3 & 3 & 3 & 3 \\
$6 \mathrm{~h}$ & 3 & 2 & 2 & 2 \\
1 day & 2 & 2 & 3 & 3 \\
2 days & 2 & 3 & 3 & $\mathbf{0}$ \\
4 days & 2 & 2 & 2 & 2 \\
8 days & 2 & 3 & 3 & 2 \\
16 days & 2 & 3 & 1 & 2 \\
60 days & 2 & 3 & $\mathbf{0}$ & $\mathbf{0}$ \\
90 days & 2 & 1 & 2 & $\mathbf{0}$
\end{tabular}

Values are the number of positive RT-qPCR results out of three tests for each experimental condition. Bold was used to present the conditions where RNA was not detected.

at intermediate or high copy numbers. At low copy number, its detection was inconsistent in samples stored at low temperatures and doubtful in those stored above freezing temperatures.

\section{Persistence of Inactivated HAV on Non-porous Surfaces}

Figures 2A,B shows that inactivated HAV was still detectable on the 90th day of storage on stainless steel or PVC at $4^{\circ} \mathrm{C}$ when the initial load was $2.5 \times 10^{6}$ copies. At this concentration, time $\times$ temperature $(p<0.0001)$, time $\times$ surface $(p=0.0302)$, and time $\times$ surface $\times$ temperature $(p=0.0251)$ interactions were observed. This results in similar inactivated HAV detection regardless of the storage conditions tested, except at 90 days, when differences emerged between 4 and $23^{\circ} \mathrm{C}$ for both materials. At this point, $>69 \%$ of the initial inactivated $\mathrm{HAV}$ was detected on PVC and stainless steel at $4^{\circ} \mathrm{C}$, compared to $<17 \%$ at $23^{\circ} \mathrm{C}$.

When the initial inactivated HAV load dried on the material surfaces was smaller (Figures 2C,D), the amount detected by RTqPCR dropped to less than $15 \%$ within 4 days at all temperatures. In fact, time was the only significant factor $(p<0.0001)$. On stainless steel, inactivated HAV was barely detectable $(0.33 \%)$ on day 16 at $23^{\circ} \mathrm{C}$ and not detected at all on day 60 or 90 or on day 90 at $4^{\circ} \mathrm{C}$. It was detected on PVC at $4^{\circ} \mathrm{C}(0.33 \%)$ and at $23^{\circ} \mathrm{C}(0.50 \%)$ on day 90 . Experiments with 250 genome copies per surface unit gave highly inconsistent results (not shown).

\section{Persistence of Inactivated HAV on Blueberries}

As shown in Figure 3, inactivated HAV at high copy numbers on blueberries remained fully detectable up to 90 days at $-20^{\circ} \mathrm{C}$. At this temperature, time $(p<0.0001)$, and concentration $(p=0.0001)$, each had a significant effect on detection but did not interact statistically. From $30 \mathrm{~min}$ to 16 days, time and concentration interacted $(p=0.0023)$ as did time and temperature $(p=0.0002)$. The $22 \%$ drop from $2.5 \times 10^{6}$ within $24 \mathrm{~h}$ at $4^{\circ} \mathrm{C}$ is significant $(p=0.0002)$, as is the subsequent drop to only $5 \%$ of the initial load by day 16 . Stored at $-20^{\circ} \mathrm{C}$, the same initial load gave erratic assay results, but these did not vary significantly from one time point to the next, notwithstanding the apparent outlier at 90 days. In the case of 25,000 copies per berry, the overall change was smaller, since even the first assay detected less than $50 \%$ of this number. Detection was down to $2 \%$ on days 8 and 16. Temperature made little difference over this time interval. Although detection peaked at $87 \%$ on day 60 at $-20^{\circ} \mathrm{C}$, this value was not significantly different from that measured at the 30 min point.

\section{DISCUSSION}

In this study, we measured the persistence of inactivated HAV under different conditions of temperature, initial load, medium, and surface in order to investigate the potential influence of non-infectious viral particles on the assessment of risks of enteric illness spreading via foods and food-handling surfaces. Our results showed that at medium-to-high copy numbers of RNA, inactivated HAV associated with non-infectious virions could persist for long periods in suspension or ice, on stainless steel or PVC and on blueberries. As mentioned elsewhere, few molecular detection methods discriminate between genetic

TABLE 2 | Detection of inactivated $\mathrm{HAV}$ in PBS stored at $-80^{\circ} \mathrm{C},-20^{\circ} \mathrm{C}, 4^{\circ} \mathrm{C}$, and $23^{\circ} \mathrm{C}$.

\begin{tabular}{|c|c|c|c|c|c|c|c|c|c|c|c|c|c|}
\hline \multirow{2}{*}{\multicolumn{2}{|c|}{$\begin{array}{l}\text { Temperature }\left({ }^{\circ} \mathrm{C}\right) \\
\text { Genome copies/sample }\end{array}$}} & \multicolumn{3}{|c|}{-80} & \multicolumn{3}{|c|}{-20} & \multicolumn{3}{|c|}{4} & \multicolumn{3}{|c|}{23} \\
\hline & & 250 & 25,000 & $2.5 \mathrm{E} 6$ & 250 & 25,000 & $2.5 \mathrm{E} 6$ & 250 & 25,000 & 2.5E6 & 250 & 25,000 & 2.5E6 \\
\hline \multirow[t]{9}{*}{ Time } & $0.5 \mathrm{~h}$ & 1 & 2 & 2 & 2 & 2 & 2 & 2 & 2 & 2 & 0 & 2 & 2 \\
\hline & $6 \mathrm{~h}$ & 0 & 1 & 2 & 1 & 1 & 1 & 0 & 2 & 2 & 1 & 1 & 2 \\
\hline & 1 day & 2 & 2 & 1 & 1 & 2 & 2 & 2 & 2 & 2 & 0 & 1 & 2 \\
\hline & 2 days & 0 & 2 & 2 & 0 & 1 & 2 & 0 & 1 & 2 & 0 & 2 & 2 \\
\hline & 4 days & 0 & 2 & 2 & 1 & 2 & 2 & 0 & 1 & 2 & 1 & 2 & 2 \\
\hline & 8 days & 1 & 2 & 1 & 0 & 1 & 2 & 0 & 0 & 2 & 0 & 2 & 2 \\
\hline & 16 days & 1 & 1 & 1 & 1 & 1 & 1 & 0 & 1 & 1 & 0 & 1 & 1 \\
\hline & 60 days & 1 & 1 & 2 & 0 & 2 & 2 & 0 & 1 & 2 & 0 & 0 & 1 \\
\hline & 90 days & 1 & 2 & 2 & 0 & 1 & 1 & 0 & 2 & 1 & 0 & 1 & 2 \\
\hline
\end{tabular}

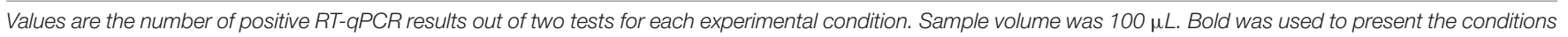
where RNA was not detected. 


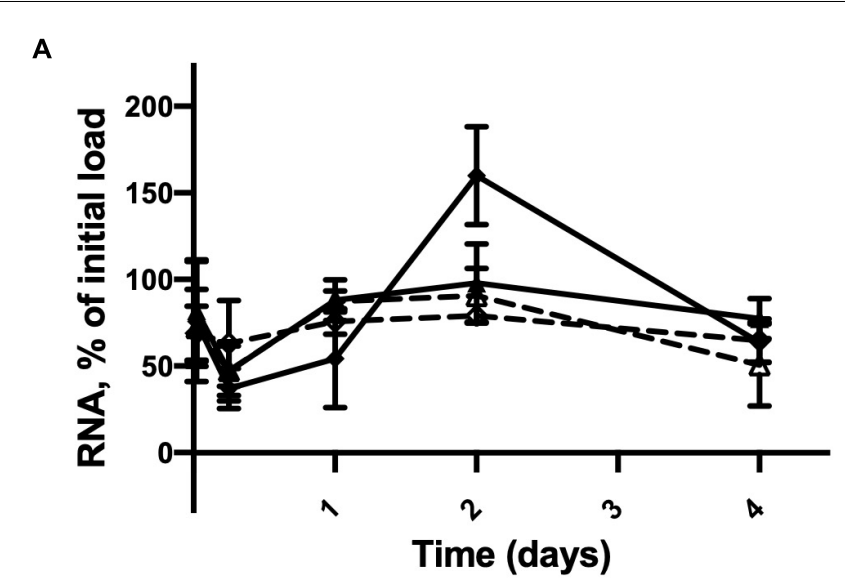

C

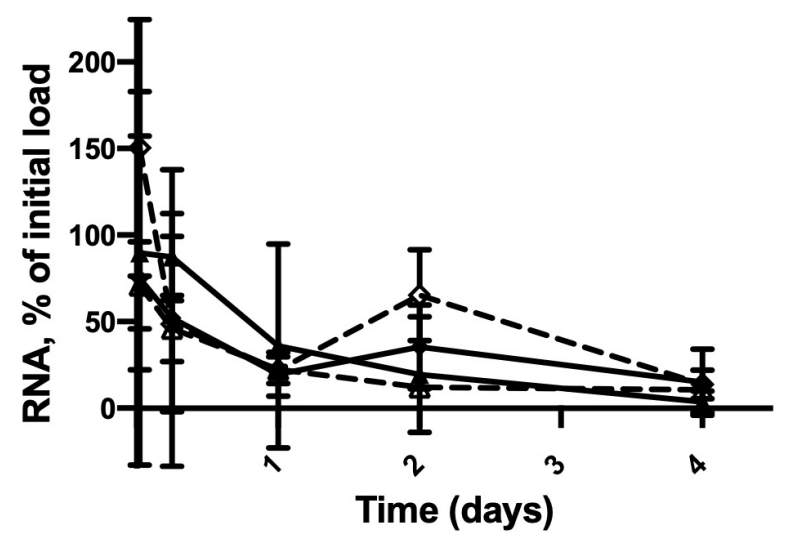

B

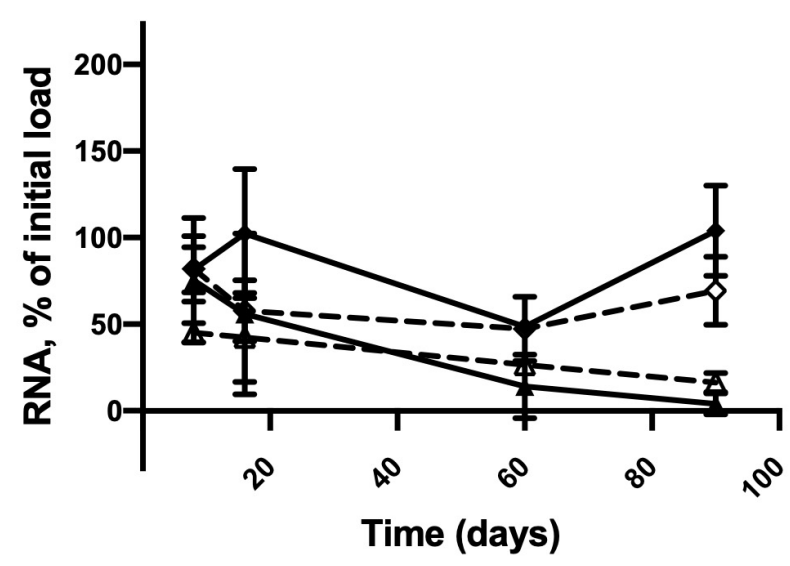

D

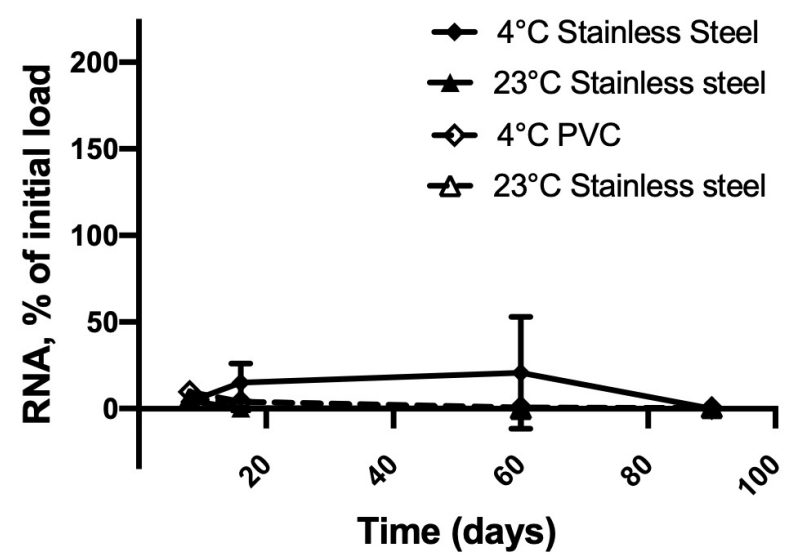

FIGURE 2 | Persistence of inactivated HAV dried on inert material surfaces initially at $2.5 \times 10^{6}$ genome copies per unit (disk, diameter $1 \mathrm{~cm}$ ) from (A) 30 min to 4 days and (B) 8 days to 90 days and at $2.5 \times 10^{4}$ genome copies per unit from (C) 30 min to 4 days and (D) 8 days to 90 days at $4^{\circ} \mathrm{C}$ on SS ( $\bullet-$ ), $23^{\circ} \mathrm{C}$ on SS $(-), 4^{\circ} \mathrm{C}$ on PVC $(-\diamond \cdot)$, and $23^{\circ} \mathrm{C}$ on PVC $(--A-*)$. Plotted values are means of 3 repetitions \pm standard deviation.

material and truly infectious viruses detected in foods. However, reference methods such as ISO 15216-1:2017 for the detection of enteric viruses in food matrices (Anonymous, 2017) and the United States standard from the Bacteriological Analytical Manual on the detection of HAV in foods (Williams-Woods et al., 2017) and methods in development such as ddPCR, next-generation sequencing (Coudray-Meunier et al., 2015; Bartsch et al., 2018), or direct lysis (Sun et al., 2019; Rajiuddin et al., 2020) are all based entirely on genome detection. The present study shows how test results based solely on RNA detection could be misleading and that overreliance on them could be prejudicial to businesses under investigation with regard to a suspected outbreak of viral gastroenteritis.

It is generally agreed that mRNA is relatively unstable, with a half-life varying from a few minutes (Bernstein et al., 2002; Selinger et al., 2003) to several hours (Krowczynska et al., 1985; Shyu et al., 1989; Sharova et al., 2009) depending on the species. The persistence of detectable viral RNA in the environment has received relatively little attention. It has been shown that the murine norovirus (MNV-1) genome can persist on stainless steel for up to 24 days at room temperature (Escudero et al., 2012).
In the same study, purified human NoV RNA (GI or Norwalk virus and GII or Snow mountain virus) could be detected for up to 7 days. Under similar conditions, purified Norwalk virus RNA appeared to remain detectable for $24 \mathrm{~h}$ (D'Souza et al., 2006). These findings are consistent with our results, which suggest that RNA breaks down quickly on stainless steel at room temperature. However, our study differs from those of Escudero et al. (2012) and D'Souza et al. (2006) since we used heat-inactivated virions rather than purified RNA in order to include damaged capsids in our conditions. Furthermore, we chose molecular-biology-grade water rather than PBS to elute inactivated HAV and thereby avoided possible inhibition of the RT-qPCR reaction by the buffer. Our results nevertheless show that under conditions routinely encountered in the food distribution and consumption chain, inactivated HAV can persist for periods much longer than mRNA.

Our results show that inactivated HAV can remain detectable at levels that vary relatively little over time when suspended at copy numbers ranging from $2.5 \times 10^{4}$ to $2.5 \times 10^{6}$ in sterile molecular-biology-grade water stored at $-80^{\circ} \mathrm{C}$ or $-20^{\circ} \mathrm{C}$. These temperatures are recommended in standard methods 

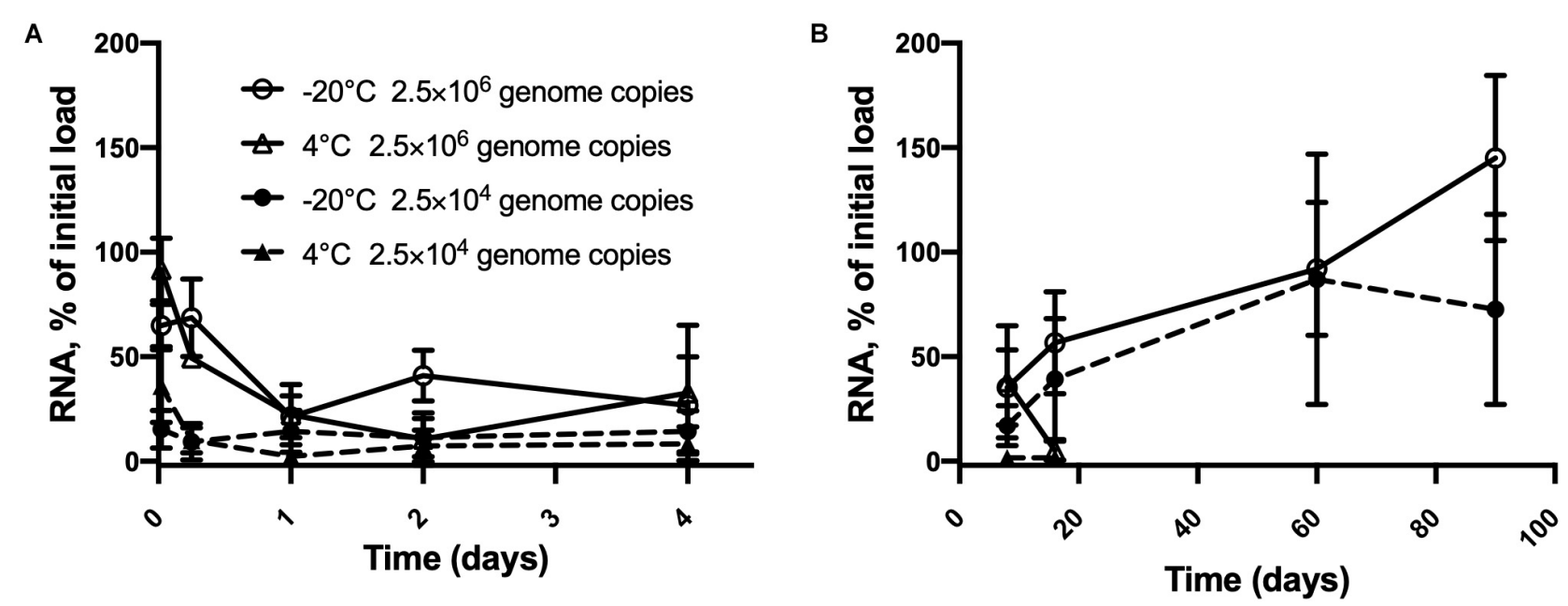

FIGURE 3 | Persistence of inactivated HAV dried on blueberries at two initial loads from (A) 30 min to 4 days and (B) 8 days to 90 days. $2.5 \times 10^{6}$ genome copies per blueberry at $-20^{\circ} \mathrm{C}(-)$ and $4^{\circ} \mathrm{C}(--\mathbf{A}-\cdot)$ and $2.5 \times 10^{4}$ genome copies per blueberry at $-20^{\circ} \mathrm{C}(-\bullet)$ and $4^{\circ} \mathrm{C}(-\boldsymbol{\star}-)$ Plotted values are means of 3 repetitions \pm standard deviation.

of conserving viral genomes over long periods (Anonymous, 2017; Williams-Woods et al., 2017). We compared them to refrigeration $\left(4^{\circ} \mathrm{C}\right)$ and room temperature $\left(23^{\circ} \mathrm{C}\right)$ using the same copy numbers. These initial loads can remain $8 \%$ detectable (a modest reduction of $1.1 \mathrm{log}$ ) after 90 days at $23^{\circ} \mathrm{C}$. The dynamics appear to vary considerably with copy number, and at least $75 \%$ of the initial inactivated HAV load may be detected at the 90-day point even when starting at 25,000 genome copies per sample. However, the error bars were large, and further analyses are required to corroborate this hypothesis. Single-stranded RNA viruses have been shown to persist for up to 18 days in autoclaved Milli Q water and wastewater stored at $20^{\circ} \mathrm{C}$ and for 28 days in filtered seawater stored at room temperature (Tsai et al., 1995; Limsawat and Ohgaki, 1997), possibly due to the presence of microorganisms (Tsai et al., 1995; Limsawat and Ohgaki, 1997). Our results show that in sterile, ribonuclease-free water, viral RNA from inactivated HAV can persist at least three times longer at $4^{\circ} \mathrm{C}$ or room temperature.

Inactivated HAV was detectable in PBS but quantification was difficult at high copy numbers and not possible at low or intermediate numbers, due likely to inhibition of RT-qPCR reactions. The $C t$ values of the test samples and the positive controls were highly variable. Although it is known that salts can inhibit the PCR reaction (Rossen et al., 1992; Schrader et al., 2012), RNA persistence could still be evaluated qualitatively in PBS since several samples were positive for 90 days.

Although inactivated HAV also degraded quickly on blueberries at $4^{\circ} \mathrm{C}$, it could still be detected after 16 days. It has been shown that MNV-1 RNA and GII human norovirus remain detectable for at least 14 days on lettuce kept at $4^{\circ} \mathrm{C}$ or at room temperature (Escudero et al., 2012). Since the persistence of virion infectiousness is affected by environmental conditions (Bae et al., 2014; Leblanc et al., 2019) as well as intrinsic characteristics of the virus species (Cannon et al., 2006; Lamhoujeb et al., 2008; Provost et al., 2011), it is not surprising that the initial RNA copy number, the storage temperature, and the type of surface have a strong influence on the persistence of detectable RNA associated with inactivated virions. The liquid used to elute the virus from the test materials and fruit could also have affected the results, since inactivated HAV detected in PBS dropped over time at room temperature, $4^{\circ} \mathrm{C}$ and $-20^{\circ} \mathrm{C}$ starting from lower copy numbers, compared to results obtained when using water. Persistence of detectable RNA under these conditions also seems to be influenced by viral species, strain, and the composition of the contaminating medium (D'Souza et al., 2006; Escudero et al., 2012).

On blueberries stored at $-20^{\circ} \mathrm{C}$, inactivated HAV could be detected at levels close to the initial load for up to 90 days. This needs to be taken into consideration, given that frozen berries can be stored for long periods by distributors and subsequently by consumers (Hutin et al., 1999; Collier et al., 2014; Müller et al., 2015). For this reason, frozen berries have been implicated on numerous occasions in outbreaks of foodborne viral gastroenteritis and are closely monitored by government agencies (reviewed by Tavoschi et al., 2015; Nasheri et al., 2019). Regardless of the variety of treatments used to reduce the infectious viral load on the surfaces of frozen produce, our results suggest that residual inactivated virus may persist for several months at low temperatures, and its detection could be interpreted as the presence of infectious virus.

The standard deviation of a few of the results obtained for blueberries needs explaining, especially in the case of storage at $-20^{\circ} \mathrm{C}$. Berries are known for their content of phenolic substances and are highly valued by consumers for their antioxidant properties (Cooke et al., 2005; Gilbert et al., 2014; Olas, 2018). However, some of these compounds have been reported to inhibit PCR reactions (John, 1992; Wei et al., 2008; Schrader et al., 2012). In fact, this is a recurring obstacle to the detection of enteric viruses on fruits, and various methods of reducing the amount of inhibitory substance in samples 
for analysis have been investigated (Bartsch et al., 2016b; Sun et al., 2019). In the present study, no purification step was carried out on the samples. In addition, slow freezing at $-20^{\circ} \mathrm{C}$ followed by thawing could have exacerbated the release of phenolic compounds (de Ancos et al., 2000; Reque et al., 2014). Reque et al. (2014) also showed an increase in the activity of anthocyanins in frozen blueberries after 3 months of storage followed by a decrease during the subsequent 3 months. Lastly, the presence of pectin found in blueberries may also inhibit RTqPCR (Suther and Moore, 2019). These findings are consistent with the significant variations seen in our detections of HAV RNA at 60 and 90 days of storage.

As our results suggest, the persistence of viral RNA on surfaces, on fruits, and in suspension could contribute considerably to positive results of tests intended to detect infectious viruses throughout the food chain. In order to prevent misinterpretation of the real risk to consumers, the detection method should include some means of differentiating between infectious and non-infectious virions. This subject has been examined widely (Nuanualsuwan and Cliver, 2002; Baert et al., 2008; Lamhoujeb et al., 2008; Parshionikar et al., 2010; Sánchez et al., 2012; Moreno et al., 2015; Zhang et al., 2019; EscuderoAbarca et al., 2020). Methods in development have been described in the literature, but none has been standardized to date. Although the efficacy of previous enzymatic treatments was debatable (Nuanualsuwan and Cliver, 2002, 2003; Baert et al., 2008; Lamhoujeb et al., 2008), several new strategies are now available. Pretreatment with proteinase $\mathrm{K}$ to degrade already damaged capsids followed by ribonuclease to cleave the viral RNA released was an obvious first approach (Nuanualsuwan and Cliver, 2002). Infectious HAV, poliovirus1, and feline calicivirus can be selected by such means if the viral particles are previously inactivated by UV, sodium hypochlorite, or heat. However, in the case of heat inactivation of MNV-1, the correlation between the number of infectious particles and the number of genome copies was poor (Baert et al., 2008). Detection of heat-inactivated NoV genetic matter could be reduced substantially by this treatment in conjunction with NASBA (Lamhoujeb et al., 2008). In a study of persistence on stainless steel at room temperature, treatment with ribonuclease alone was found not to allow detection of infectious MNV-1 particles only, since this enzyme could not degrade viral RNA inside intact non-infectious particles (Leblanc et al., 2019). Combining RT-qPCR with a non-enzymatic pretreatment such as propidium monoazide has been proposed to differentiate between infectious and non-infectious viral particles (Sánchez et al., 2012; Leifels et al., 2015; Quijada et al., 2016). This approach has been found more effective than RNase treatment for detecting infectious HAV in conjunction with thermal inactivation (Sánchez et al., 2012). Although these pretreatments show potential for allowing the detection of infectious virions only, they are limited by the inactivation of the particles of interest by damage to the capsid (Nuanualsuwan and Cliver, 2003; Zhang et al., 2019).

By performing the RT-qPCR analyses on the day that the inactivated HAV was recovered from solutions or eluted from food contact surfaces and blueberries, the bias potentially introduced by sample storage and thawing was eliminated. However, there could have been inter plate differences between our experimental replicates over the 90 -day period. Therefore, we implemented several procedural controls on each assay plate and presented the results in light of those controls, which we believe would have alerted us to deviations in technical consistency. We are aware that heat-inactivating treatment could enhance RNA stabilization with potential capsid ribonucleoproteins, a phenomenon previously described when heating poliovirus at $72^{\circ} \mathrm{C}, 2 \mathrm{~min}$ (Knight et al., 2013). However, additional data are required to further establish this hypothesis under our conditions.

This study provides a general idea of the extent to which enteropathogenic viruses introduced by sporadic or systemic contamination might persist as detectable RNA at different points in the industrial food chain. RNA associated with inactivated HAV does persist considerably over time on non-porous surfaces and on foods at a wide range of temperatures. The persistence at temperatures above freezing, although lesser, is cause for concern. These results show that molecular methods of detecting viruses throughout the food production and distribution chain, especially in the context of investigating outbreaks and possibly ordering onerous product recalls, need to include suitable means of distinguishing between non-infectious residues of viruses and truly infectious particles. This could take the form of a sample pre-treatment protocol.

\section{DATA AVAILABILITY STATEMENT}

The raw data supporting the conclusions of this article will be made available by the authors, without undue reservation.

\section{AUTHOR CONTRIBUTIONS}

MT-F designed the study, performed the experiments and analyses, and wrote the manuscript. EJ provided technical support and assisted the writing of the manuscript. JJ supervised every step of the study. All authors contributed to the article and approved the submitted version.

\section{FUNDING}

Funding for this study was received in the form of research grants from the Natural Sciences and Engineering Research Council of Canada (NSERC, RDCPJ 522816-17) and Consortium de recherche et innovations en bioprocédés industriels au Québec (CRIBIQ 2017-038-C29). MT-F is the recipient of NSERC and Fonds de Recherche du Québec - Nature et Technologies scholarships.

\section{ACKNOWLEDGMENTS}

We thank Stephen Davids for his critical review of the manuscript. 


\section{REFERENCES}

Ancos, B., Ibaxñez, E., Reglero, G., and Cano, M. P. (2000). Frozen storage effects on anthocyanins and volatile compounds of raspberry fruit. J. Agric. Food Chem. 48, 873-879. doi: 10.1021/jf990747c

Anonymous (2017). Microbiology of the Food Chain - Horizontal Method for Determination of Hepatitis A Virus and Norovirus Using Real-Time RT-PCR. Part 1: Method for Quantification - ISO 15216-1:2017, 1 Edn. Genève: International Organization for Standardization.

Atmar, R. L., Opekun, A. R., Gilger, M. A., Estes, M. K., Crawford, S. E., Neill, F. H., et al. (2008). Norwalk virus shedding after experimental human infection. Emerg. Infect. Dis. 14, 1553-1557. doi: 10.3201/eid1410.0 80117

Bae, S.-C., Park, S. Y., Kim, A.-N., Oh, M.-H., and Ha, S.-D. (2014). Survival of Hepatitis A virus on various food-contact surfaces during 28days of storage at room temperature. Food Res. Int. 64, 849-854. doi: 10.1016/j.foodres.2014.08. 023

Baert, L., Wobus, C. E., Coillie, E. V., Thackray, L. B., Debevere, J., and Uyttendaele, M. (2008). Detection of murine norovirus 1 by using plaque assay, transfection assay, and real-time reverse transcription-PCR before and after heat exposure. Appl. Environ. Microbiol. 74, 543-546. doi: 10.1128/AEM.010 39-07

Bartsch, C., Höper, D., Mäde, D., and Johne, R. (2018). Analysis of frozen strawberries involved in a large norovirus gastroenteritis outbreak using next generation sequencing and digital PCR. Food Microbiol. 76, 390-395. doi: 10. 1016/j.fm.2018.06.019

Bartsch, C., Szabo, K., Dinh-Thanh, M., Schrader, C., Trojnar, E., and Johne, R. (2016a). Comparison and optimization of detection methods for noroviruses in frozen strawberries containing different amounts of RT-PCR inhibitors. Food Microbiol. 60, 124-130. doi: 10.1016/j.fm.2016.07.005

Bartsch, S. M., Lopman, B. A., Ozawa, S., Hall, A. J., and Lee, B. Y. (2016b). Global economic burden of norovirus gastroenteritis. PLoS One 11:e0151219. doi: 10.1371/journal.pone.0151219

Bernard, H., Faber, M., Wilking, H., Haller, S., Höhle, M., Schielke, A., et al. (2014). Large multistate outbreak of norovirus gastroenteritis associated with frozen strawberries, Germany, 2012. Eurosurveillance 19:20719. doi: 10.2807/15607917.ES2014.19.8.20719

Bernstein, J. A., Khodursky, A. B., Lin, P.-H., Lin-Chao, S., and Cohen, S. N. (2002). Global analysis of MRNA decay and abundance in Escherichia Coli at singlegene resolution using two-color fluorescent DNA Microarrays. Proc. Natl. Acad. Sci. U.S.A. 99, 9697-9702. doi: 10.1073/pnas.112318199

Biziagos, E., Passagot, J., Crance, J. M., and Deloince, R. (1988). Long-term survival of Hepatitis A virus and poliovirus type 1 in mineral water. Appl. Environ. Microbiol. 54, 2705-2710.

Bonifait, L., Charlebois, R., Vimont, A., Turgeon, N., Veillette, M., Longtin, Y., et al. (2015). Detection and quantification of airborne norovirus during outbreaks in healthcare facilities. Clin. Infect. Dis. 61, 299-304. doi: 10.1093/cid/civ321

Butot, S., Putallaz, T., and Sánchez, G. (2008). Effects of sanitation, freezing and frozen storage on enteric viruses in berries and herbs. Int. J. Food Microbiol. 126, 30-35. doi: 10.1016/j.ijfoodmicro.2008.04.033

Canadian Food Inspection Agency (2017). "2014-2016 Viruses in Fresh Berries and Frozen Fruits." Reference Material. Available online at: https://www.inspection.gc.ca/food-safety-for-industry/chemical-residuesmicrobiology/food-safety-testing-bulletins/2017-09-20/viruses-in-freshberries-and-frozen-fruits/eng/1506954705347/1506954705706 (accessed October 18, 2017)

Cannon, J. L., Papafragkou, E., Park, G. W., Osborne, J., Jaykus, L.-A., and Vinjé, J. (2006). Surrogates for the study of Norovirus stability and inactivation in the environment: a comparison of murine Norovirus and Feline Calicivirus. J. Food Prot. 69, 2761-2765. doi: 10.4315/0362-028X-69.11.2761

Chatziprodromidou, I. P., Bellou, M., Vantarakis, G., and Vantarakis, A. (2018). Viral outbreaks linked to fresh produce consumption: a systematic review. J. Appl. Microbiol. 124, 932-942. doi: 10.1111/jam.13747

Collier, M. G., Khudyakov, Y. E., Selvage, D., Adams-Cameron, M., Epson, E., Cronquist, A., et al. (2014). Outbreak of Hepatitis A in the USA associated with frozen pomegranate arils imported from Turkey: an epidemiological case study. Lancet Infect. Dis. 14, 976-981. doi: 10.1016/S1473-3099(14)70883-7
Cook, N., Bertrand, I., Gantzer, C., Pinto, R. M., and Bosch, A. (2018). Persistence of Hepatitis A virus in fresh produce and production environments, and the effect of disinfection procedures: a review. Food Environ. Virol. 10, 253-262. doi: 10.1007/s12560-018-9349-1

Cooke, D., Steward, W. P., Gescher, A. J., and Marczylo, T. (2005). Anthocyans from fruits and vegetables - does bright colour signal cancer chemopreventive activity? Eur. J. Cancer 41, 1931-1940. doi: 10.1016/j.ejca.2005.06.009

Costafreda, M. I., Bosch, A., and Pintó, R. M. (2006). Development, evaluation, and standardization of a real-time TaqMan reverse transcription-PCR assay for quantification of Hepatitis $\mathrm{A}$ virus in clinical and shellfish samples. Appl. Environ. Microbiol. 72, 3846-3855. doi: 10.1128/AEM.026 60-05

Coudray-Meunier, C., Fraisse, A., Martin-Latil, S., Guillier, L., Delannoy, S., Fach, P., et al. (2015). A comparative study of digital RT-PCR and RT-QPCR for quantification of Hepatitis A virus and norovirus in lettuce and water samples. Int. J. Food Microbiol. 201, 17-26. doi: 10.1016/j.ijfoodmicro.2015.0 2.006

Croci, L., Dubois, E., Cook, N., de Medici, D., Schultz, A. C., China, B., et al. (2008). Current methods for extraction and concentration of enteric viruses from fresh fruit and vegetables: towards international standards. Food Anal. Methods 1, 73-84. doi: 10.1007/s12161-008-9025-4

D’Souza, D. H., Sair, A., Williams, K., Papafragkou, E., Jean, J., Moore, C., et al. (2006). Persistence of Caliciviruses on environmental surfaces and their transfer to food. Int. J. Food Microbiol. 108, 84-91. doi: 10.1016/j.ijfoodmicro.2005.10. 024

Escudero, B. I., Rawsthorne, H., Gensel, C., and Jaykus, L. A. (2012). Persistence and transferability of noroviruses on and between common surfaces and foods. J. Food Prot. 75, 927-935. doi: 10.4315/0362-028X.JFP-11-460

Escudero-Abarca, B. I., Goulter, R. M., Arbogast, J. W., Leslie, R. A., Green, K., and Jaykus, L.-A. (2020). Efficacy of alcohol-based hand sanitizers against human norovirus using RNase-RT-QPCR with validation by human intestinal enteroid replication. Lett. Appl. Microbiol. 71, 605-610. doi: 10.1111/lam.13393

Franklin, N., Camphor, H., Wright, R., Stafford, R., Glasgow, K., and Sheppeard, V. (2019). Outbreak of Hepatitis A genotype IB in Australia associated with imported frozen pomegranate arils. Epidemiol. Infect. 147, e74. doi: 10.1017/ S0950268818003515

Gilbert, J. L., Olmstead, J. W., Colquhoun, T. A., Levin, L. A., Clark, D. G., and Moskowitz, H. R. (2014). Consumer-assisted selection of blueberry fruit quality traits. HortScience 49, 864-873. doi: 10.21273/HORTSCI.49.7.864

Girard, M., Mattison, K., Fliss, I., and Jean, J. (2016). Efficacy of oxidizing disinfectants at inactivating murine norovirus on ready-to-eat foods. Int. J. Food Microbiol. 219, 7-11. doi: 10.1016/j.ijfoodmicro.2015.11.015

Girard, M., Ngazoa, S., Mattison, K., and Jean, J. (2010). Attachment of noroviruses to stainless steel and their inactivation, using household disinfectants. J. Food Prot. 73, 400-404. doi: 10.4315/0362-028X-73.2.400

Herman, K. M., Hall, A. J., and Gould, L. H. (2015). Outbreaks attributed to fresh leafy vegetables, United States, 1973-2012. Epidemiol. Infect. 143, 3011-3021. doi: $10.1017 /$ S0950268815000047

Hutin, Y. J. F., Pool, V., Cramer, E. H., Nainan, O. V., Weth, J., Williams, I. T., et al. (1999). A multistate, foodborne outbreak of Hepatitis A. N. Engl. J. Med. 340, 595-602. doi: 10.1056/NEJM199902253400802

Jacobsen, K. H. (2018). Globalization and the changing epidemiology of Hepatitis A virus. Cold Spring Harb. Perspect. Med. 8, a031716. doi: 10.1101/cshperspect. a031716

Jean, J., Morales-Rayas, R., Anoman, M.-N., and Lamhoujeb, S. (2011). Inactivation of Hepatitis A virus and norovirus surrogate in suspension and on food-contact surfaces using pulsed UV light (pulsed light inactivation of food-borne viruses). Food Microbiol. 28, 568-572. doi: 10.1016/j.fm.2010.11.012

John, M. E. (1992). An efficient method for isolation of RNA and DNA from plants containing polyphenolics. Nucleic Acids Res. 20, 2381.

Knight, A., Li, D., Uyttendaele, M., and Jaykus, L.-A. (2013). A critical review of methods for detecting human noroviruses and predicting their infectivity. Crit. Rev. Microbiol. 39, 295-309. doi: 10.3109/1040841X.2012.709820

Kokkinos, P., Kozyra, S. I., Lazic, M., Bouwknegt, S., Rutjes, K., Willems, R., et al. (2012). Harmonised investigation of the occurrence of human enteric viruses in the leafy green vegetable supply chain in three European countries. Food Environ. Virol. 4, 179-191. doi: 10.1007/s12560-012-9087-8 
Koopmans, M., and Duizer, E. (2004). Foodborne viruses: an emerging problem. Int. J. Food Microbiol. 90, 23-41. doi: 10.1016/S0168-1605(03)00169-7

Krowczynska, A., Yenofsky, R., and Brawerman, G. (1985). Regulation of messenger RNA stability in mouse erythroleukemia cells. J. Mol. Biol. 181, 231-239. doi: 10.1016/0022-2836(85)90087-7

Lamhoujeb, S., Fliss, I., Ngazoa, S. E., and Jean, J. (2008). Evaluation of the persistence of infectious human noroviruses on food surfaces by using realtime nucleic acid sequence-based amplification. Appl. Environ. Microbiol. 74, 3349-3355. doi: 10.1128/AEM.02878-07

Leblanc, D., Gagné, M.-J., Poitras, É, and Brassard, J. (2019). Persistence of murine norovirus, bovine rotavirus, and Hepatitis A virus on stainless steel surfaces, in spring water, and on blueberries. Food Microbiol. 84, 103257. doi: 10.1016/j.fm. 2019.103257

Leifels, M., Jurzik, L., Wilhelm, M., and Hamza, I. A. (2015). Use of ethidium monoazide and propidium monoazide to determine viral infectivity upon inactivation by heat, UV- exposure and chlorine. Int. J. Hygiene Environ. Health 218, 686-693. doi: 10.1016/j.ijheh.2015.02.003

Lemon, S. M., Ott, J. J., Damme, P. V., and Shouval, D. (2018). Type A viral Hepatitis: a summary and update on the molecular virology, epidemiology, pathogenesis and prevention. J. Hepatol. 68, 167-184. doi: 10.1016/j.jhep.2017. 08.034

Limsawat, S., and Ohgaki, S. (1997). Fate of liberated Viral RNA in wastewater determined by PCR. Appl. Environ. Microbiol. 63, 2932-2933. doi: 10.1128/ AEM.63.7.2932-2933.1997

Lopman, B., Gastañaduy, P., Park, G. W., Hall, A. J., Parashar, U. D., and Vinjé, J. (2012). Environmental transmission of norovirus gastroenteritis. Curr. Opin. Virol. 2, 96-102. doi: 10.1016/j.coviro.2011.11.005

Mattison, K., Karthikeyan, K., Abebe, M., Malik, N., Sattar, S. A., Farber, J. M., et al. (2007). Survival of Calicivirus in foods and on surfaces: experiments with feline Calicivirus as a surrogate for norovirus. J. Food Prot. 70, 500-503. doi: 10.4315/0362-028X-70.2.500

Mbithi, J. N., Springthorpe, V. S., Boulet, J. R., and Sattar, S. A. (1992). Survival of Hepatitis A virus on human hands and its transfer on contact with animate and inanimate surfaces. J. Clin. Microbiol. 30, 757-763.

Mbithi, J. N., Springthorpe, V. S., and Sattar, S. A. (1991). Effect of relative humidity and air temperature on survival of Hepatitis A virus on environmental surfaces. Appl. Environ. Microbiol. 57, 1394-1399.

Moreno, L., Aznar, R., and Sánchez, G. (2015). Application of viability PCR to discriminate the infectivity of Hepatitis A virus in food samples. Int. J. Food Microbiol. 201, 1-6. doi: 10.1016/j.ijfoodmicro.2015.02.012

Müller, L., Schultz, A. C., Fonager, J., Jensen, T., Lisby, M., Hindsdal, K., et al. (2015). Separate norovirus outbreaks linked to one source of imported frozen raspberries by molecular analysis, Denmark, 2010-2011. Epidemiol. Infect. 143, 2299-2307. doi: 10.1017/S0950268814003409

Nasheri, N., Vester, A., and Petronella, N. (2019). Foodborne viral outbreaks associated with frozen produce. Epidemiol. Infect. 147, e291. doi: 10.1017/ S0950268819001791

Nuanualsuwan, S., and Cliver, D. O. (2002). Pretreatment to avoid positive RTPCR results with inactivated viruses. J. Virol. Methods 104, 217-225. doi: 10. 1016/S0166-0934(02)00089-7

Nuanualsuwan, S., and Cliver, D. O. (2003). Capsid functions of inactivated human Picornaviruses and feline Calicivirus. Appl. Environ. Microbiol. 69, 350-357. doi: 10.1128/AEM.69.1.350-357.2003

Olas, B. (2018). Berry phenolic antioxidants - implications for human health? Front. Pharmacol. 9:78. doi: 10.3389/fphar.2018.00078

Parshionikar, S., Laseke, I., and Fout, G. S. (2010). Use of Propidium monoazide in reverse transcriptase PCR to distinguish between infectious and noninfectious enteric viruses in water samples. Appl. Environ. Microbiol. 76, 4318-4326. doi: 10.1128/AEM.02800-09

Patel, M. M., Hall, A. J., Vinjé, J., and Parashar, U. D. (2009). Noroviruses: a comprehensive review. J. Clin. Virol. 44, 1-8. doi: 10.1016/j.jcv.2008.10.009

Provost, K., Dancho, B. A., Ozbay, G., Anderson, R. S., Richards, G. P., and Kingsley, D. H. (2011). Hemocytes are sites of enteric virus persistence within oysters. Appl. Environ. Microbiol. 77, 8360-8369. doi: 10.1128/AEM.068 $87-11$

Quijada, N. M., Fongaro, G., Barardi, C. R. M., Hernández, M., and RodríguezLázaro, D. (2016). Propidium monoazide integrated with QPCR enables the detection and enumeration of infectious enteric RNA and DNA viruses in clam and fermented sausages. Front. Microbiol. 7:2008. doi: 10.3389/fmicb.2016. 02008

Rajiuddin, S. M., Jensen, T., Hansen, T. B., and Schultz, A. C. (2020). An optimised direct lysis method for viral RNA extraction and detection of foodborne viruses on fruits and vegetables. Food Environ. Virol. 12, 226-239. doi: 10.1007/s12560020-09437-x

Randazzo, W., and Sánchez, G. (2020). Hepatitis A infections from food. J. Appl. Microbiol. 129, 1120-1132. doi: 10.1111/jam.14727

Reque, P. M., Steffens, R. S., Jablonski, A., Flôres, S. H., Rios, A. O., and de Jong, E. V. (2014). Cold storage of blueberry (Vaccinium Spp.) fruits and juice: anthocyanin stability and antioxidant activity. J. Food Comp. Anal. 33, 111-116. doi: 10.1016/j.jfca.2013.11.007

Rossen, L., Nørskov, P., Holmstrøm, K., and Rasmussen, O. F. (1992). Inhibition of PCR by components of food samples, microbial diagnostic assays and DNAextraction solutions. Int. J. Food Microbiol. 17, 37-45. doi: 10.1016/01681605(92)90017-W

Sánchez, G., Elizaquível, P., and Aznar, R. (2012). Discrimination of infectious Hepatitis A viruses by Propidium monoazide real-time RT-PCR. Food Environ. Virol. 4, 21-25. doi: 10.1007/s12560-011-9074-5

Sattar, S. A., Springthorpe, V. S., Karim, Y., and Loro, P. (1989). Chemical disinfection of non-porous inanimate surfaces experimentally contaminated with four human pathogenic viruses. Epidemiol. Infect. 102, 493-505. doi: 10. $1017 /$ S0950268800030211

Schrader, C., Schielke, A., Ellerbroek, L., and Johne, R. (2012). PCR inhibitors occurrence, properties and removal. J. Appl. Microbiol. 113, 1014-1026. doi: 10.1111/j.1365-2672.2012.05384.x

Selinger, D. W., Saxena, R. M., Cheung, K. J., Church, G. M., and Rosenow, C. (2003). Global RNA half-life analysis in Escherichia Coli reveals positional patterns of transcript degradation. Genome Res. 13, 216-223. doi: 10.1101/gr. 912603

Severi, E., Verhoef, L., Thornton, L., Guzman-Herrador, B. R., Faber, M., Sundqvist, L., et al. (2015). Large and prolonged food-borne multistate Hepatitis A outbreak in europe associated with consumption of frozen berries, 2013 to 2014. Eurosurveillance 20, 21192. doi: 10.2807/1560-7917.ES2015.20.29. 21192

Sharova, L. V., Sharov, A. A., Nedorezov, T., Piao, Y., Shaik, N., and Ko, M. S. H. (2009). Database for MRNA half-life of 19977 genes obtained by DNA microarray analysis of pluripotent and differentiating mouse embryonic stem cells. DNA Res. 16, 45-58. doi: 10.1093/dnares/dsn030

Shyu, A. B., Greenberg, M. E., and Belasco, J. G. (1989). The C-Fos transcript is targeted for rapid decay by two distinct MRNA degradation pathways. Genes Dev. 3, 60-72. doi: 10.1101/gad.3.1.60

Sun, B., Bosch, A., and Myrmel, M. (2019). Extended direct lysis method for virus detection on berries including droplet digital RT-PCR or real time RTPCR with reduced influence from inhibitors. J. Virol. Methods 271, 113638. doi: 10.1016/j.jviromet.2019.04.004

Suresh, M., Harlow, J., and Nasheri, N. (2019). Evaluation of porcine gastric mucin assay for detection and quantification of human norovirus in fresh herbs and leafy vegetables. Food Microbiol. 84, 103254. doi: 10.1016/j.fm.2019.10 3254

Suther, C., and Moore, M. D. (2019). Quantification and discovery of PCR inhibitors found in food matrices commonly associated with foodborne viruses. Food Sci. Hum. Wellness 8, 351-355. doi: 10.1016/j.fshw.2019. 09.002

Tavoschi, L., Severi, E., Niskanen, T., Boelaert, F., Rizzi, V., Liebana, E., et al. (2015). Food-borne diseases associated with frozen berries consumption: a historical perspective, European Union, 1983 to 2013. Eurosurveillance 20, 21193. doi: 10.2807/1560-7917.ES2015.20.29.21193

Tjon, G. M. S., Coutinho, R. A., van den Hoek, A., Esman, S., Wijkmans, C. J., Hoebe, C. J. P. A., et al. (2006). High and persistent excretion of Hepatitis A virus in immunocompetent patients. J. Med. Virol. 78, 1398-1405. doi: 10.1002/ jmv.20711

Tsai, Y. L., Tran, B., and Palmer, C. J. (1995). Analysis of viral RNA persistence in seawater by reverse transcriptase-PCR. Appl. Environ. Microbiol. 61, 363-366. doi: 10.1128/AEM.61.1.363-366.1995

U.S. Food and Drug Administration (2020a). FDA Sampling Frozen Berries for Harmful Viruses. Silver Spring, MD: FDA. 
U.S. Food and Drug Administration (2020b). Microbiological Surveillance Sampling: FY 19-20 Frozen Berries (Strawberries, Raspberries and Blackberries). Silver Spring, MD: FDA.

Vasickova, P., Pavlik, I., Verani, M., and Carducci, A. (2010). Issues concerning survival of viruses on surfaces. Food Environ. Virol. 2, 24-34. doi: 10.1007/ s12560-010-9025-6

Verhaelen, K., Bouwknegt, M., Carratalà, A., Lodder-Verschoor, F., Diez-Valcarce, M., Rodríguez-Lázaro, D., et al. (2013). Virus transfer proportions between gloved fingertips, soft berries, and lettuce, and associated health risks. Int. J. Food Microbiol. 166, 419-425. doi: 10.1016/j.ijfoodmicro.2013.07.025

Wei, T., Lu, G., and Clover, G. (2008). Novel approaches to mitigate primer interaction and eliminate inhibitors in multiplex PCR, demonstrated using an assay for detection of three strawberry viruses. J. Virol. Methods 151, 132-139. doi: 10.1016/j.jviromet.2008.03.003

Wheeler, C., Vogt, T. M., Armstrong, G. L., Vaughan, G., Weltman, A., Nainan, O. V., et al. (2005). An outbreak of Hepatitis A associated with green onions. N. Engl. J. Med. 353, 890-897. doi: 10.1056/NEJMoa050855

WHO (2015). . WHO Estimates of the Global Burden of Foodborne Diseases: Foodborne Disease Burden Epidemiology Reference Group
2007-2015. Publications on Foodborne Diseases. Genève: World Health Organisation.

Williams-Woods, J., Hartman, G., and Burkhardt, W. (2017). Laboratory Methods BAM 26B: Detection of Hepatitis A Virus in Foods. Silver Spring, MD: U.S. Food and Drug Administration.

Zhang, Y., Qu, S., and Xu, L. (2019). Progress in the study of virus detection methods: the possibility of alternative methods to validate virus inactivation. Biotechnol. Bioeng. 116, 2095-2102. doi: 10.1002/bit.27003

Conflict of Interest: The authors declare that the research was conducted in the absence of any commercial or financial relationships that could be construed as a potential conflict of interest.

Copyright () 2021 Trudel-Ferland, Jubinville and Jean. This is an open-access article distributed under the terms of the Creative Commons Attribution License (CC BY). The use, distribution or reproduction in other forums is permitted, provided the original author(s) and the copyright owner(s) are credited and that the original publication in this journal is cited, in accordance with accepted academic practice. No use, distribution or reproduction is permitted which does not comply with these terms. 